\title{
Incluir as comunidades marginalizadas na sociedade digital
}

\author{
José Marques de Melo
}

\section{SciELO Books / SciELO Livros / SciELO Libros}

MELO, JM. Cidadania glocal, identidade nordestina: ética da comunicação na era da internet [online]. Campina Grande: EDUEPB; Latus, 2011. 108 p. ISBN 978-85-63984-07-4. Available from SciELO Books $<$ http://books.scielo.org $>$.

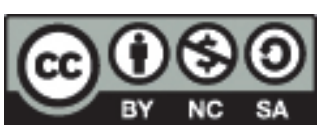

All the contents of this work, except where otherwise noted, is licensed under a Creative Commons Attribution-Non Commercial-ShareAlike 3.0 Unported.

Todo o conteúdo deste trabalho, exceto quando houver ressalva, é publicado sob a licença Creative Commons Atribuição Uso Não Comercial - Partilha nos Mesmos Termos 3.0 Não adaptada.

Todo el contenido de esta obra, excepto donde se indique lo contrario, está bajo licencia de la licencia Creative Commons Reconocimento-NoComercial-CompartirIgual 3.0 Unported. 


\section{Incluir as comunidades marginalizadas na sociedade digital $^{8}$}

Sertanejo, que peregrina pelos caminhos do mundo, há meio século, aprendi que a região situada no polígono das secas padecia não apenas da falta de água, mas da escassez de conhecimento. A solidão que sufocava nossa gente, pela precariedade das estradas, pela falta de escolas e pela distância das fontes de informação, certamente contribuiu, na estiagem cultural, para a migração dos sedentos de saber, como nutriu as levas de retirantes famintos, nos tempos de seca.

8 Texto escrito no dia 7 de março de 2009, apresentando o livro organizado pela professora Maria Salett Tauk dos Santos (Recife, UFRPE, 2009). 
Outro dia, visitando o sertão das Alagoas, onde nasci e me criei, tive a impressão de que a brecha cognitiva começava a diminuir, justamente pelo ingresso da sociedade nordestina na galáxia digital. Só no município de Santana do Ipanema, onde desfrutei minha juventude, existem três portais, que disseminam notícias sertanejas para todo o planeta.

Contudo, só elucidei a face oculta da charada, ao ler os artigos reunidos na coletânea sobre inclusão digital, competentemente organizada pela professora Maria Salett Tauk dos Santos. Percebi que, sem audiência local, aqueles projetos de comunicação regional não teriam como sustentar-se. Pois, como dizem jocosamente os pernambucanos, impregnados pelo "complexo da pitomba", não basta a iniciativa de ativistas midiáticos, sem dispor de anunciantes e sem contar com os insumos provenientes das fontes de informação. Mais do que isso: sem ter respaldo dos usuários locais, que alimentam a mística dos regionalismos.

Na medida em que avançam os projetos de democratização dos recursos da informática pelos contingentes periféricos da nossa sociedade, sem dúvida criam-se as condições para robustecer a utopia da comunicação glocal, nutrida pela altivez folkmidiática de comunidades autônomas, neutralizando a voragem 
da comunicação global, irrigada pelas matrizes pós-modernas do capitalismo predatório.

A ancoragem escolhida pela organizadora desse livro, focalizando as culturas populares como referentes para avaliar o impacto da inclusão digital na vida pernambucana, permite aos estudiosos das ciências da comunicação discernir o tamanho do "apartheid tecnológico" ou do "gap cibercultural" que outrora o mestre Luiz Beltrão denominava toscamente "marginalidade comunicacional". Trata-se de fenômeno gerado pela mesma estrutura socioeconômica que embasou a convivência dissimuladamente hostil das "casas grandes" e "senzalas" ou dos "sobrados e mocambos", descrita por Gilberto Freyre. Mas que continua a justificar a permanência dos bolsões societários, antagonizando o cotidiano dos privilegiados que usufruem, apreensivos, as delícias dos "condomínios fechados" ou dos "edifícios blindados" e dos miseráveis que vegetam, mas se divertem, nas "favelas" ou nos "cortiços", vítimas indefesas do êxodo rural ou do desemprego urbano.

Ao desfrutar saborosamente os relatos que os discípulos da professora Salett Tauk fazem dos resultados obtidos pelos agentes culturais que atuam em programas de difusão tecnológica, outrora conhecidos como extensionistas, fui-me convencendo de que se completa 
o ciclo ciberfolkcultural a que referi no recente livro Mídia e cultura popular (São Paulo, Paulus, 2008). Investigando a presença de manifestações folkcomunicacionais na internet, defrontei-me com uma avalanche sequer imaginada pelos próceres da disciplina que estuda tais fenômenos. Minha análise prévia contemplava o voluntarismo dos forjadores da cultura popular, como os cordelistas, os forrozeiros ou os vaquejadores, que buscam refúgio na internet para se comunicar com aqueles contingentes da diáspora nordestina refugiados no "sul maravilha". Agora, a inclusão digital dos excluídos sociais que engrossam as fileiras do programa "bolsa família" e congêneres tem

82 a chance de cultivar seus valores culturais nos "cybercafés" instalados pela rede pública em escolas, igrejas, sindicatos e centros comunitários, permitindo o diálogo com os produtores da cultura popular que resistem estoicamente, preservando o legado dos seus ancestrais.

Não posso absolutamente deixar de me referir à emoção que tive ao ler o último capítulo da coletânea. Trata-se da narrativa sobre o advento da cibercultura na comunidade rurbana de Águas Belas.

A cidade ali existente é o desdobramento da comunidade primitiva erigida em pleno semiárido pelos fulni-ô, tribo indígena cujo território limitava-se com o espaço ocupado 
pelos xucurus, descendentes dos caetés. Quando se deu, em princípios do século XIX, a emancipação política de Alagoas do Estado de Pernambuco, as duas tribos passaram a pertencer a unidades federativas distintas. Tal situação apenas se tornou perceptível aos "caboclos" subsistentes, depois de instituída a FUNAI. Sua missão foi a de tutelar as terras indígenas, objeto da cobiça dos desbravadores lusodescentes, naquela região, agricultores remanescentes dos que se aventuraram pelas paragens cáusticas do sertão, navegando pelos afluentes periódicos do São Francisco.

Foi numa comunidade fronteiriça entre a nação xucuru e a tribo fulni-ô que veio a se entrincheirar, em tempos remotos, meu clã batavo, tolerando o gueto afrodescendente, aglunitado no quilombo hoje conhecido como Jorge, mas negociando sua sobrevivência com os pajés dos aldeamentos caboclos remanescentes nas proximidades.

Pois bem, frequentando sazonalmente a cidade de Águas Belas, onde vivia a parcela lusodescendente da minha família, acostumei-me a reconhecer os traços culturais dos fulni-ô, seja pela participação em seus torés, rito de passagem, seja pelo consumo do seu artesanato em barro e palha para atividades lúdicas ou trabalhos escolares. 
Vítimas do alcoolismo, do absenteísmo laboral, do paternalismo estatal e do preconceito comunitário, entristecia-me a decadência do que restava dos fulni-ô, cada vez que retornava a Águas Belas. Aquele último fator de aniquilação cultural começa a ser ultrapassado pelo projeto "Conhecendo a nação fulni-ô. Vencendo preconceitos", mantido pela ONG Tonomundo. Trata-se de evidência suficiente para me convencer de que a inclusão digital pode contribuir para a inclusão social, hipótese que nutre o projeto temático idealizado pela autora dos ensaios que motivaram as pesquisas descritas e problematizadas.

Embora estrategicamente amparada pelos postulados antropológicos dos culturalistas latino-americanos Barbero, Canclini e Orozco, que embasam a vertente hegemônica da "hibridação", Salett Tauk não despista sua inspiração na tese da "mestiçagem" disseminada pelos brasileiros: Gilberto Freyre, Arthur Ramos e Câmara Cascudo, devidamente apropriada no campo comunicacional por Luiz Beltrão e Roberto Benjamin, fontes seminais da sua formação acadêmica.

Ao apresentar o referido livro, senti-me recompensado pela convivência intelectual mantida com a sua organizadora, desde os seus tempos de juventude, cujos traços permanecem nítidos no trabalho atual como líder de 
equipes como a que ensejou os capítulos referidos, cuja leitura recomendo vivamente aos jovens que hoje se iniciam na vida acadêmica. O respeito, a admiração e a estima que tenho nutrido pela professora Salett Tauk significam plena confiança no seu porvir como pesquisadora que logo se libertará das fontes canônicas para alçar voo em direção a horizontes autônomos e infinitos. 